\title{
INTERNATIONAL JOURNAL OF MICROWAVE AND WIRELESS TECHNOLOGIES
} journals.cambridge.org/mrf

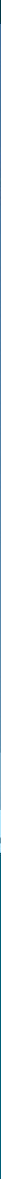


EDITOR-IN-CHIEF

Prof. Almudena Suarez,

R\&D Laboratories of Telecommunications Engineering

Universidad de Cantabria

Avenida de los Castros s/n

39005, Spain.

almudena.suarez@unican.es

\section{EDITORIAL BOARD}

Dr. Eduardo Carrasco, IT'IS, Switzerland Prof. Wenhua Chen, Tsinghua University, Beijing, China

Prof. Paolo Colantonio, Università di Tor Vergata Roma, Italy

Prof. Alessandra Costanzo, University of Bologna, Italy

Prof. Philippe Ferrari, IMEP Grenoble, France

Prof. Gaspare Galati, Università di Tor

Vergata Roma, Italy

Prof. Alessandro Galli, Sapienza

University of Rome, Italy

Prof. Antonio Garcia-Pino, University of

Vigo, Spain

Dr. Anthony Ghiotto, IMS Laboratory,

Talence, France

Prof. Shiban K Koul, Indian Institute of

Technology Delhi, India

Prof. Krzysztof S Kulpa, Warsaw

University of Technology, Poland

Prof. Asher Madjar, M2Microwaves LLC,

Philadelphia, USA and Tel Aviv University,

Israel

Prof. Francisco Medina, University of

Sevilla, Spain

Dr. Steve Nightingale, Cobham, UK

Prof. Marco Pasian, Université Pavia, Italy

Prof. Luca Perregrini, Université Pavia, Italy

Dr. Xianming Qing, Institute for

Infocomm Research, Singapore

Dr. Ruediger Quay, Fraunhofer Institute

Freiburg, Germany

Prof. Raymond Quéré, XLIM-University

of Limoges, France.

Dr. Fred Schindler, RFMD, USA

Prof. Dominique Schreurs, KU Leuwen, Belgium

Prof. Roberto Sorrentino, University of Perugia, Italy

Prof. Danielle Vanhoenacker-Janvier,

UC Louvain, Belgium

Prof. Huei Wang, NTU, Taiwan

Prof. Robert Weigel, University of

Erlangen, Germany

Dr. Hung-Wei Wu, Kun Shan University, Taiwan

Prof. Felix Yanovsky, National Aviation University, Ukraine

Prof. Alex Yarovoy, TU Delft, The

Netherlands

\section{Scope of the journal}

International Journal of Microwave

and Wireless Technologies is

interdisciplinary and application oriented, providing a platform for the microwave industry. Subjects covered include: applied electromagnetic field theory, components, analogue and mixed-signal circuits, systems, optical-microwave interactions, electromagnetic compatibility, industrial applications, biological effects and medical applications.

\section{Submission of Manuscripts}

All manuscripts should be submitted online at http://mc.manuscriptcentral. $\mathrm{com} / \mathrm{mrf}$. Please consult the instructions for authors at http://cambridge.org/mrf

\section{Subscriptions}

International Journal of Microwave and Wireless Technologies (ISSN

1759-0787) is published ten times a year in February, March, April, May, June, July, September, October, November and December. The subscription price (excluding VAT) of Volume 9 (2017) (which includes postage by air, plus electronic access) is 11042 net (US \$1944 in the USA, Canada and Mexico) for institutions; the electronic only price for institutional subscribers is $\mathrm{f758}$ net (US $\$ 1421$ in the USA, Canada and Mexico). Members of the European Microwave Association receive free online access to the Journal, and may order print subscriptions at a reduced rate for their personal use only. Single parts are $\mathrm{f133}$ (US $\$ 251$ in the USA, Canada and Mexico) plus postage. Orders, which must be accompanied by payment, may be sent to a bookseller, subscription agent or direct to the publisher: Cambridge University Press, Journals Fulfilment Dept, UPH, Shaftesbury Road, Cambridge CB2 8BS, UK; or in the USA, Canada and Mexico: Cambridge University Press, Journals Fulfillment Department, 1 Liberty Plaza, Floor 20, New York, NY, 10006, USA. EU subscribers (outside the UK) who are not registered for VAT should add VAT at their country's rate. VAT registered subscribers should provide their VAT registration number. Japanese prices for institutions are available from Kinokuniya Company Ltd, P.O. Box 55, Chitose, Tokyo 156, Japan. Copies of the journal for subscribers in the USA, Canada and Mexico are sent by air to New York to arrive with minimum delay. Periodicals postage paid at New York, NY, and at additional mailing offices. POSTMASTER: send address changes in the USA, Canada and Mexico to: International Journal of Microwave and Wireless Technologies, 1 Liberty Plaza, Floor 20, New York, NY, 10006, USA. Claims for missing issues should be made immediately on receipt of the subsequent issue.

\section{Advertising}

For all parts of the world except USA,

Canada and Mexico to Journals

Advertising: ad_sales@cambridge.org

Address enquiries in the USA,

Mexico and Canada only to:

journals_advertising@cup.org

\section{Copying}

This journal is registered with the

Copyright Clearance Center, 222

Rosewood Drive, Danvers, MA 01923,

USA. Organizations in the USA who are

also registered with C.C.C. may therefore copy material (beyond the limits permitted by sections 107 and 108 of U.S. Copyright law) subject to promotional or commercial purposes. Code 0266-4674/2017 \$16.00. ISI Tear Sheet Service, 3501 Market Street, Philadelphia, PA 19104, USA, is authorized to supply single copies of separate articles for private use only.

Organizations authorized by the Copyright Licensing Agency may also copy material subject to the usual conditions. For all other use, permission should be sought from Cambridge or the American Branch of Cambridge University Press.

\section{Internet Access}

This journal is included in Cambridge Core and can be found at cambridge.org/mrf. For further information on other Press titles access http://www.cambridge.org

(C) Cambridge University Press and the European Microwave Association 2017 Cambridge University Press, UPH, Shaftesbury Road, Cambridge CB2 8BS, United Kingdom 1 Liberty Plaza, Floor 20, New York, NY, 10006, USA USA 477 Williamstown Road, Port Melbourne, VIC 3207, Australia Ruiz de Alarcón 13, 28014 Madrid, Spain Dock House, The Waterfront, Cape Town 8001, South Africa

Printed in the United Kingdom by Bell \& Bain Ltd, Glasgow.

This journal issue has been printed on FSC ${ }^{\mathrm{TM}}$-certified paper and cover board. FSC is an independent, non-governmental, not-for-profit organization established to promote the responsible management of the world's forests. Please see www.fsc.org for information. 